\title{
The Development of Sendang Biru Beach in Malang Regency Through Marine Edutourism
}

\author{
$1^{\text {st }}$ Ronal Ridhoi \\ History Department Malang University \\ Malang, Indonesia \\ ronal.ridhoi.fis@um.ac.id \\ $2^{\text {nd }}$ Restia Minati Anggraeni \\ History Department Malang University \\ Malang, Indonesia
}

\author{
$3^{\text {rd }}$ Muhammad Bahtiar \\ History Department Malang University \\ Malang, Indonesia \\ $4^{\text {th }}$ Lutfiah Ayundasari \\ History Department Malang University \\ Malang, Indonesia
}

\author{
$5^{\text {th }}$ Marsudi \\ History Department Malang University \\ Malang, Indonesia
}

\begin{abstract}
South Malang has various coastal tourism areas. However, there is no insight to develop these beaches through the concept of edutourism. This study aims to describe the geographical conditions and potency of Sendang Biru Beach to be developed as a marine edutourism field. This research uses a descriptive qualitative method by perusing documents, books, journals and online news carefully, and in-depth interviews with stakeholders. The results of this study indicates that Sendang Biru Beach can be developed as a marine edutourism site, because this area has a lot of maritime potential such as diverse marine animals and a pretty good beach environment. However, to achieve that, it needed support from the government, local residents and tourists. They must support the marine edutourism on the developing coastal areas.
\end{abstract}

Keywords: development, Sendang Biru, marine, edutourism

\section{INTRODUCTION}

The tourism sector is a main potency in the development of an area. Tourism has become a separate industry that plays an important role in the regional economy, especially for residents around the tourist sites. [1] argued that the tourism sector can open up employment opportunities for people around the tourist attraction. It proved by the emergence of microeconomics, such as souvenir sellers, snack food sellers, and so forth. The development of the tourism sector in a country will attract other sectors to develop because its products are needed to support the tourism industry, such as agriculture, animal husbandry, plantations, folk crafts, increased employment opportunities, etc. [2], [3].
However, this paper is not discussed more about the tourism industry in Indonesia. Researchers focuses more on the study of the maritime potency in a region, especially Sendang Biru Beach. So far this area is well known as the Tempat Pelelangan Ikan (TPI) and as a gateway to cross into the conservation area of Sempu Island in the south. Even though Sendang Biru also has the natural potential to be developed as a marine edutourism. The study of edutourism in Indonesia still limited to be accessed. Eko makes a media edutourism based on video in the coastal area, but that not focused on marine edutourism [4]. So this paper just focused on marine edutourism in southern Malang.

Why marine edutourism? As revealed by Koroy, that the opportunities and potency of Indonesia's marine tourism are growing rapidly [5]. However it has not been a major contribution to the national economy of Indonesia. Similar to Sendang Biru Beach, which has considerable economic and natural potential but has not been fully utilized yet by the Government of Malang Regency, even the people in Sendang Biru itself.

The study of southern Malang always related socio economic aspect, start from colonial to contemporary period. This because southern Malang experienced more about the cultivation and labourers since colonial period [6]. The study of coastal areas in the southern Malang is limited. Even though southern Malang has many of beaches which shows their beauty, one of them is Sendang Biru Beach. This beach is one of the beach resorts located in Sendang Biru Hamlet, Tambaksari Village, Sumbermanjing Wetan District, Malang Regency. Sendang Biru Beach has long been known as a 
tourist place before the advent of other beach resorts such as Watu Leter Beach, Batu Bengkung, Goa Cina, Asmara Bay, and so on. Across from Sendang Biru Beach, there is a beautiful island for conservation, namely Sempu Island. The island is maintained its ecosystem out of human reach. According to Yudi (local resident), in the past there were still many people who entered the Sempu Island area. However, for now it is not allowed on the grounds to protect the flora and fauna of the island [7].

Based on the Besluit van den Gouverneur Generaal van Nederlandsch Indie, No. 46, Stbl No. 69, March 15, 1928, Sempu Island was designated a conservation area. The determination of the $877 \mathrm{Ha}$ island is based on several factors, such as botanical, aesthetic, and topographic. Selian was also due to the potential of flora, fauna, and its location close to the island of Java which gives an overview of the condition of the forests and terrestrial ecosystems of the island of Java. The designation of forest areas as nature reserves due to natural conditions, unique flora and fauna requires protection for the interests of present and future science. Communities around Sendang Biru Beach believe that the existence of Sempu Island is a blessing in itself [8].

Therefore this paper aims to explain the natural potential of Sendang Biru Beach, especially the marine environment. This is done so that the potential can be utilized as an educational tour. Later visitors and local residents are expected to not only uses Sendang Biru Beach as a tourist location, fishing and fish auction, but also learn about the marine potency on this beach. Author also explains and explore more about the using of Sendang Biru Beach as a marine edutourism, because this concept according to Georgia and Dimitrios, would be the sector of the economy that is developing fast and get more popularity to the region. Nowadays edutourism has become tourist and learning activity which includes primary or secondary part of the trip [9]

\section{METHOD}

This research uses descriptive qualitative method. The qualitative research is research that focuses attention with a variety of methods that include a naturalistic interpretation approach to the subject study. In this case qualitative research includes the subject being studied and a collection of various empirical data, case studies, interviews, texts of observations as well as various ways of collecting data. In this paper the researcher collected information with various data collection procedures such as interviews, literature review observations as well as from previous research [10].

This study uses primary data and secondary data. Primary data is data collected directly in the field. Retrieval of primary data using purposive sampling method based on certain considerations and reasons such as determining the location of data collection. Whereas secondary data is data obtained from searches of reports on research results and results of activities in the same location, scientific publications, regional regulations, data from government agencies, private and nongovernmental organizations as well as regional historical data [5].

This research was conducted in two stages. First is the initial observation conducted on 30 April 2019 to 31 May 2019. Researchers collected sources in the form of Sendang Biru Chronicles, archives from BPS Malang Regency, annual reports of the Malang Regency Disbudpar, various news about Sendang Biru Beach, both written and online. From the first stage, preliminary data were obtained on the general description of Sendang Biru Beach, the initial history of the area and the socio-economic conditions of the surrounding communities.

The second phase of this research was conducted on 17 June 2019 to 9 August 2019. At this stage the researchers conducted in-depth interviews with various parties, such as fishermen, local residents, managers of tourist attractions, and visitors (tourists) on Sendang Biru Beach. In addition, the study also conducted in-depth interviews with academics, village officials, and the local government of Malang Regency. From various primary and secondary data, information was obtained on the general description and a brief history of the Sendang Biru area since the colonial period. In addition, data was also obtained about the maritime potential of Sendang Biru Area to be developed as a marine tourism edu. Next will be explained in each section below.

\section{RESULTS AND DISCUSSION}

\section{A. General Description of Sendang Biru Beach}

Object and the area coverage of this research is a southern part of Malang Regency, that is Sendang Biru Beach. It located in Tambakrejo Village, Sumbermanjing Wetan District, Malang Regency. This area situated $69 \mathrm{~km}$ from Malang City through Turen and Sumbermanjing Wetan. Sendang Biru is a very well-known as a coastal area and dropping fish also [11]. Malang Regency was very famous by various beaches. This is reasonable to see from the length of the coastline of Malang Regency as a whole is $85.92 \mathrm{~km}$ with an area of water around $1696.35 \mathrm{~km} 2$. From this area, the Sumbermanjing Wetan area has the largest coastline of around $536.29 \mathrm{~km} 2$ [12].

Geographically, the location of Sendang Biru is in the coordinates 8o26'- 8o30' South Latitude and $112^{0} 38^{\prime}-112^{\circ} 43^{\prime}$ East Longitude. The Sendang Biru area is a hamlet directly adjacent to the Kedung Banteng Village, Tambaksari Village and Sitiarjo Village. Sendang Biru Hamlet is also directly adjacent to the Sempu Strait which is a marine area that has abundant natural resources, such as tuna and coral reefs (see fig 2). 


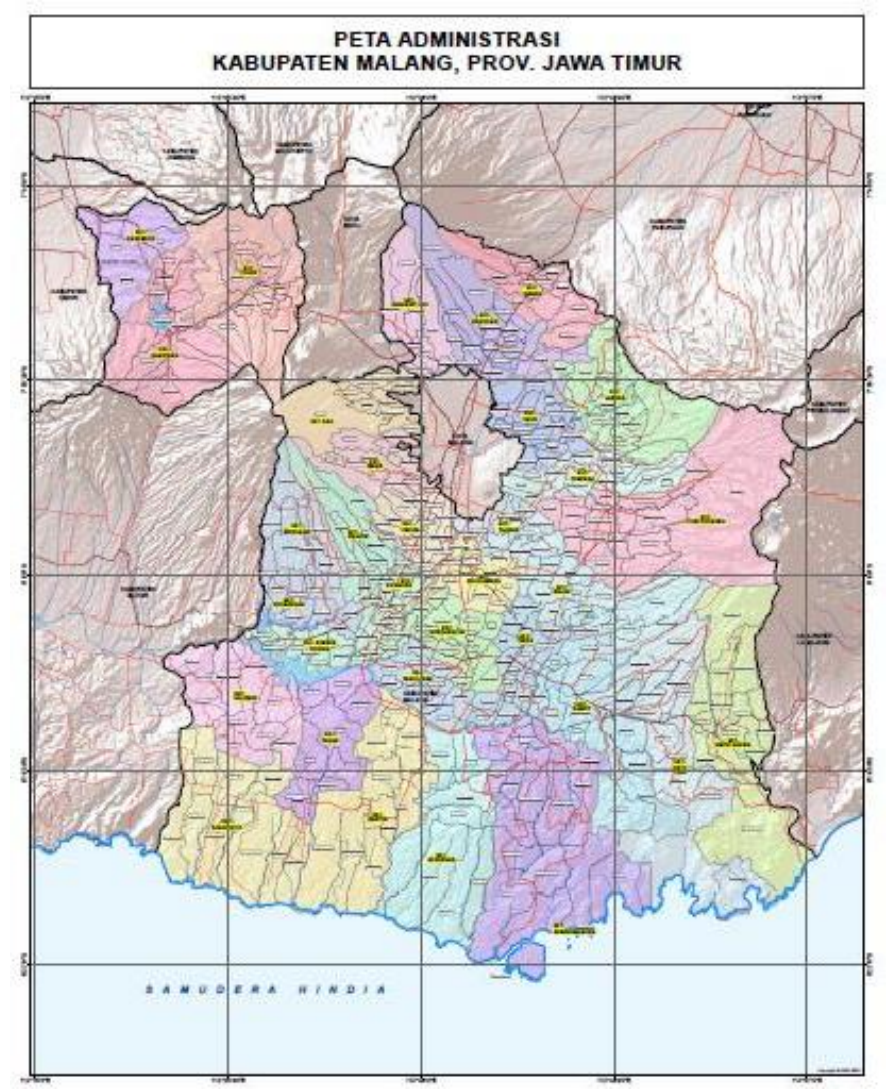

Fig. 1. Map of Malang Regency. (source: adobted from dokumen KRB Malang 2013-2017 [13])

The sea is a natural resource that is very influential in the lives of the surrounding community. There are various natural wealth available such as fish, oil, seaweed and diverse flora and fauna. In addition, the potential that can be developed is to make it a transportation route, a port, a place of recreation, and other developments. Indonesian territory is very famous for its diverse marine potential. It can also be seen from one of the coastal areas of Malang Regency, Sendang Biru. Sendang Biru as one of the highly developed coastal areas in Malang Regency. The coastal area of Sendang Biru Beach is a large scale fishery industry area. With marketing to various regions such as Tuban, Surabaya, Jakarta, and so on.

Blue spring fishing industry is one of the income for the area itself and for the community. The fishermen who are there are of course very dependent on the existence of the fishing industry. The fishermen become suppliers of fish in the fishing industry in Sendang Biru. Blue spring conditions as a fishing industry area certainly has a fairly complete infrastructure such as the Fish Auction Place (TPI). Meanwhile, the most dominant seafood is tuna (baby tuna). The fish is excellent for the fishermen and the community in Sendang Biru.

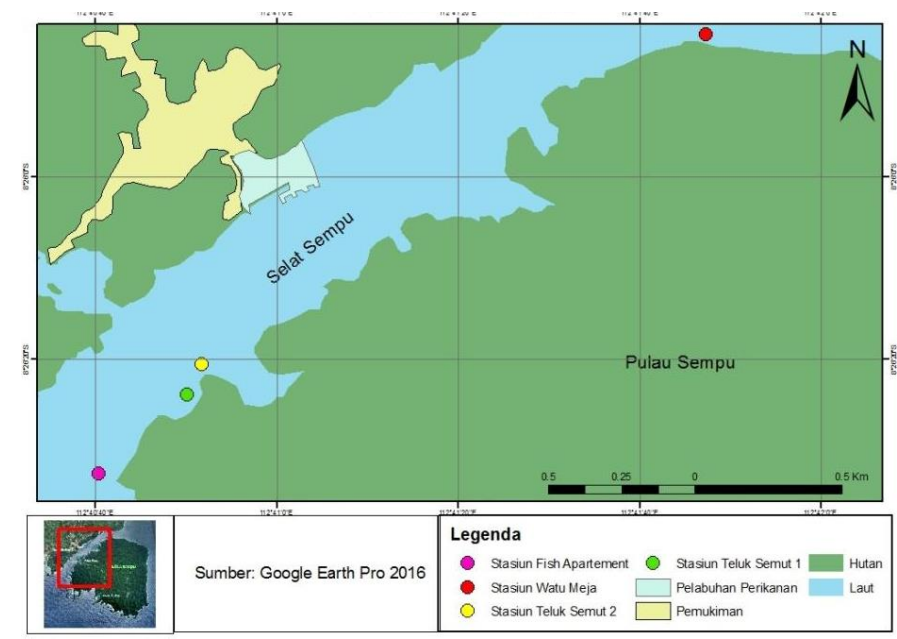

Fig. 2. Map of TPI and settlement of Sendang Biru, 2017 [14].

TPI in the area is very helpful for fishermen and middlemen (contractor) to carry out fish trading transactions. However, these conditions are inversely proportional to beach tourism. Senang Biru beach tourism is not as crowded as it used to be. Currently more tourists are traveling to Sempu Island, which is directly opposite Sendang Biru beach. Sendang Biru natural conditions that are not as natural as before as well as less supporting tourism infrastructure makes the lack of tourist interest. In addition, the cleanliness of the blue spring waters is also lacking, one of which is influenced by fishermen loading and unloading fish. Sendang Biru is an area famous for its fishing industry not for its natural attractions. So now Sendang Biru is used as the Fisheries Industry Center in Malang Regency.

\section{B. From Forest (wana) to the Pasamuan Sendang Biru}

Sendang Biru is famous as a beach tourism destination in Malang Regency. This area is a beach with white sand that is quite clean (see fig 3). It also has the largest dock in South Malang specifically for tuna fishing and several other types of fish. The origin of Sendang Biru Hamlet is from the meaning of the word spring (spring). This blue spring is one of the sources of people's lives. All needs can be fulfilled from Sendang Biru water especially for bathing, washing up to daily consumption needs. Blue does not only mean blue water, but also signifies purity and cleanliness [14].

It is estimated that the Sendang Biru area has been used as a settlement since the beginning of the 20th century. This was evidenced by the discovery of the area of forest (alas / wana) Mount Malang the first time by someone named Mbah Satiti. The location is in the southeast of Sitiarjo Village. Formerly this area was in the form of dense forest that had not been touched by humans, therefore Mbah Satiti called it Wana Sendang Biru. Wana means forest, Sendang Biru means the 
source of clear water. So, it can be interpreted that in the beginning this area was still in the form of dense forest in which there was a clear water source [15].

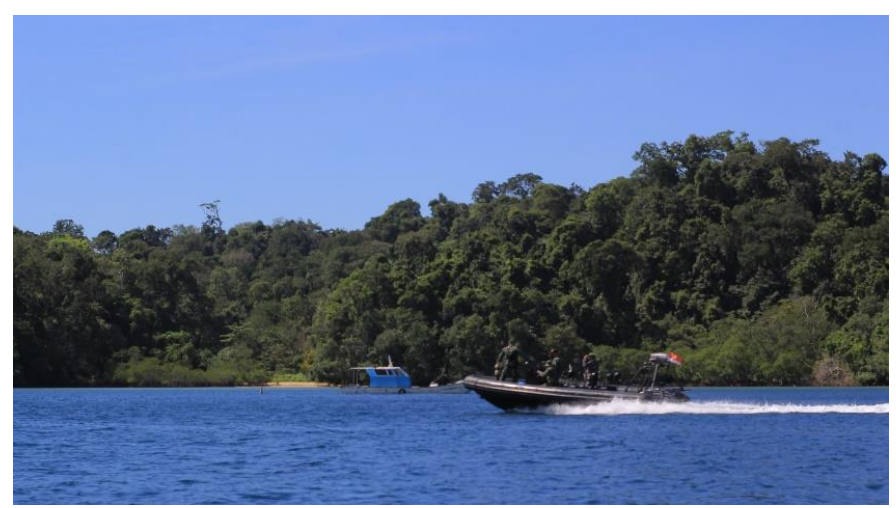

Fig. 3. The panorama at Sendang Biru Beach (source: personal documentation, 2019)

In 1925 Mbah Satiti and some of his students came to the area of South Malang Mountain (now Sendang Biru) to open the first place for evangelism. Mbah Satiti Together with her friends then made new roads as well as establishing a hut for gospel teaching. The hut was built near the spring which is considered the main water source for the residents of Sendang Biru (see fig 4).

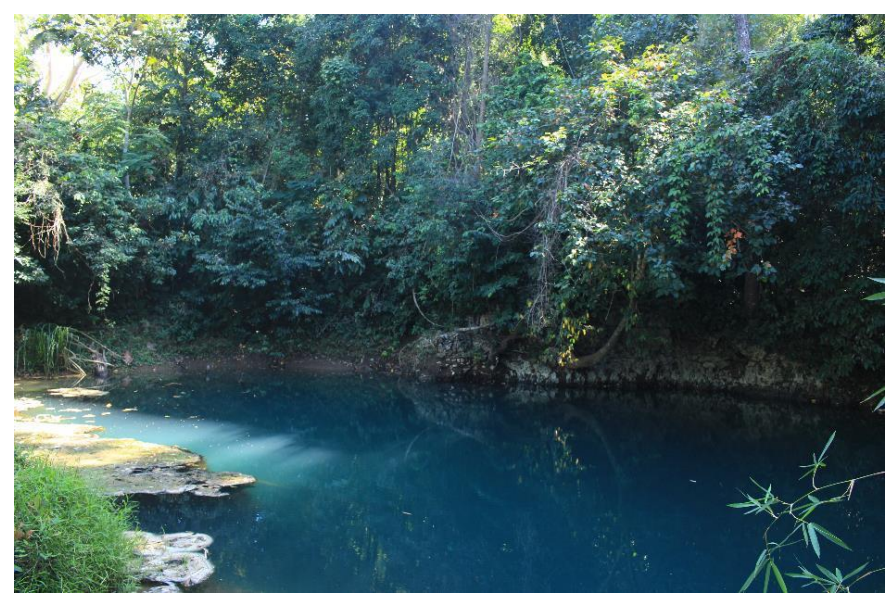

Fig. 4. Researchers at Blue springwater which becoming the site for the origin of naming Sendang Biru (source: personal documentation, 2019).

The opening of the village was not easy. Before leaving, Mbah Satiti and friends asked permission from Rev. S. Devriss of Pasamuan Suwaru. It also took care of licensing to the Dutch colonial government to open new land in the forest. In the beginning, in 1927 a cabin was set up north of spring. The establishment of the cottage has received permission from the

Dutch government. Thus, Mbah Satiti began to spread Christian influence in the region [15].

Gradually, near the location of the blue spring, Mbah Satiti and her students opened residential land and yards. Mbah Satiti allowed the people to live on the land, but had to convert to Christianity. People who live receive land allotment for their homes and land for farming [13]. Every Sunday the residents of the settlement are not allowed to work, because they have to pray in the Pasamuan Sendang Biru cottage.

Until in 1931 based on permission from the Dutch colonial government, Sendang Biru was legalized as a hamlet under the administration of Sitiarjo Village. But in that year Mbah Satiti was getting older, even though his followers were growing. Finally, the task as a priest in Pasamuan Sendang Biru was handed over to his successor named Mr. Mintasih alias Ngademo. After that, Pak Ngademo became the first village chief at Sendang Biru [15].

Until the independence period and continued in the 1980s many migrants came to Sendang Biru Hamlet, they were Bugis and Madurese. The Bugis tribe has long been known as a nomadic tribe that has migrated for centuries from South Sulawesi to various other areas in Indonesia to Australia by sea [16][17]. One of the Bugis tribes is that one of them is influenced by their traditions. With this tradition also makes the Bugis tribe famous in fisheries, trade and can establish relationships with other tribes. The Bugis began to move to Sendang Biru in the early 1980s with the aim of establishing a fishing industry like the one in Makassar [16]. In the process the Bugis tribe experienced considerable difficulties because fishermen in the Blue Spring area at that time were not too many. Blue Sendang community there are still many who work as farmers.

Then conflict between tribes, namely Bugis and Javanese in Sendang Biru. The conflict occurred because the Javanese people felt unacceptable to the Bugis tribe who came and then took the natural resources that existed at Sendang Biru beach. Then in the 1990s the conflict could be resolved by mediating between the Javanese and Buginese people. After that, with the abundant natural potential and competition that is not too strong, the community has pioneered the fishing industry in Sendang Biru. The Fishing Industry is also assisted by the government by establishing a Fish Auction Place [7]. Until now the Sendang Biru area is famous for its Fishery Industry as well as its heterogeneous community.

\section{The Rise of Marine Edutourism in Sendang Biru Regency}

The concept of education or education can also be called educational tourism (edutourism) is the concept of tourism by applying informal education about knowledge to tourists who visit a tourist attraction. In these places visitors can do tourist activities while learning with a fun method. Through edutainment (a pleasant educational process), the learning 
process can be more easily understood and remembered because of the fun method. Edutourism can be describe as general interest learning while traveling and purpose learning and traveling [3], [10]. The form of edutourism programs can be separated as ecotourism (ecotourism), historical tourism (heritage tourism), rural tourism, community tourism and student exchanges between educational institutions (student exchange) [23].

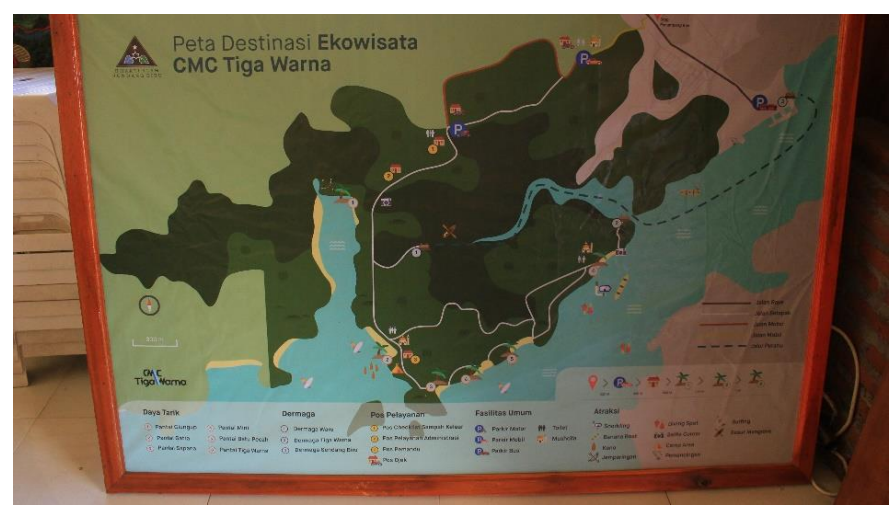

Fig. 5. Map of Ecotourism in Sendang Biru (source: The Foundation of Clungup Mangrove Conservation, Sendang Biru, Malang Indonesia).

As the fig 5 shown above, Sendang Biru already developed as edutourism, especially the CMS Foundation focused on ecotourism in CMC Tigawarna. Ecotourism is a part of edutourism. Nevertheless, this papers focused on the development of marine potency as learning resources. So, the development of Sendang Biru Beach can be included on edutourism.

Edutourism is intended as a program where the participants of the tour activities take a tour at a particular place in the group with the main goal of getting direct learning experience related to the location visited. In addition, education can also promote sustainability and turn young tourists into responsible consumers and future travelers and preserve nature. This is a unique opportunity for young people to discover what they want to do in their future. In addition, the tour also seems to have contributed to their decision in choosing a university [9].

Because the subject of this research is the coastal area and its maritime potential, the explanation will focus on marine tourism. As United Nation Environment Programme (UNEP) explained that a large portion of the world's population inhabits coastal areas, and most of these populations benefit from the use of coastal and marine resources [5]. The activity of utilizing natural resources to fulfill social and economic systems would affect the environmental processes and ecological systems. Therefore, the potential of the surrounding coastal and marine areas is very important to be managed further, especially on Sendang Biru Beach.
One of the strength of Sendang Biru Beach is the marine potency, especially tuna fish (see fig 4). There are various fish in the Sendang Biru sea, such as tuna, baby tuna, lemuruh, tongkol, layang, cakalang dan ekor merah [16]. But, in fact, south coast of Malang Regency is a producer of the great quality of tuna. Specifically yellow fin tuna, also known as yellow fin, has been exported to several parts of the world, especially in Europe [17]. Moreover, as WWF reported in 2016, Sendang Biru Beach well-known as the region that produces the best handline tuna in Indonesia. That is the place that famous for its tuna potentials [18][19].

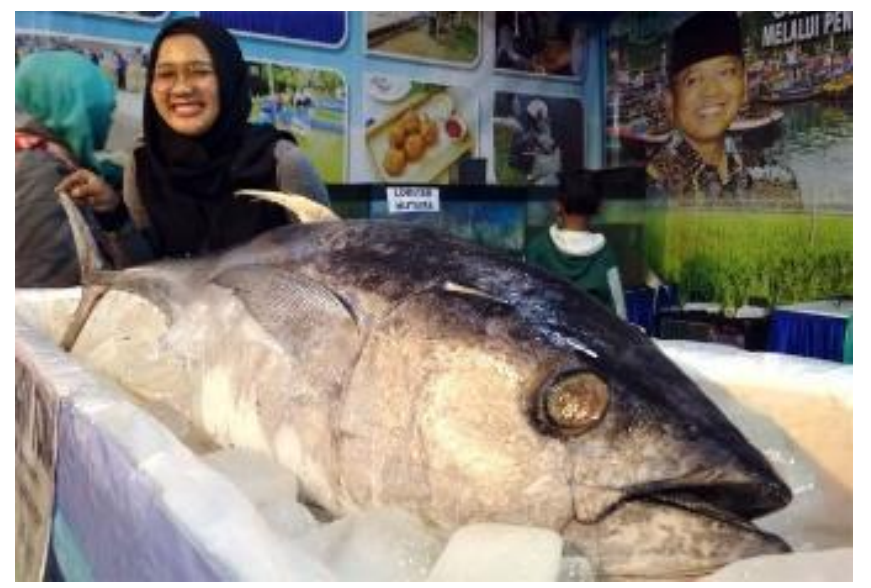

Fig. 6. Yellow fin tuna at TPI Sendang Biru [20].

Regarding the management and development of Sendang Biru beach itself, it can be said that it still needs a lot of attention. Because in some cases it is still lacking, as in terms of public facilities for visitors need further development. But on the other hand it is also quite good in terms of management such as hygiene there is maintained, payment counters and the tariff is also affordable, which is around 5000 rupiahs. In this paper is explained that Sendang Biru Beach in South Malang has a potency to be developed as a marine educational site.

In terms of management, there is a certain party responsible in Sendang Biru area. A small structure has been formed in the management of tourist attractions under the Malang District Tourism Office. Then in terms of cleanliness, the beach is quite clean so it is nice and comfortable to visit. One thing that makes Sendang Biru beach has more value is its natural condition and also its geographical location which is adjacent to Sempu Island. That way visitors can rent a boat on Sendang Biru beach and go around some of the beaches around it. Even visitors can cross to Sempu Island and stop on the outskirts of the beach to relax seeing the scenery or playing clear water.

However, this beach still has some weaknesses. The main weakness in Sendang Biru beach in terms of management is that the opening and closing hours are uncertain. If the condition is quiet, the ticket window was not opened. Then 
sometimes the negligence of the ticket window guard does not give a ticket to enter Sendang Biru Beach. Then the lack of supporting facilities for visitors. Like a playground for children or just a bench to sit (see fig 5).

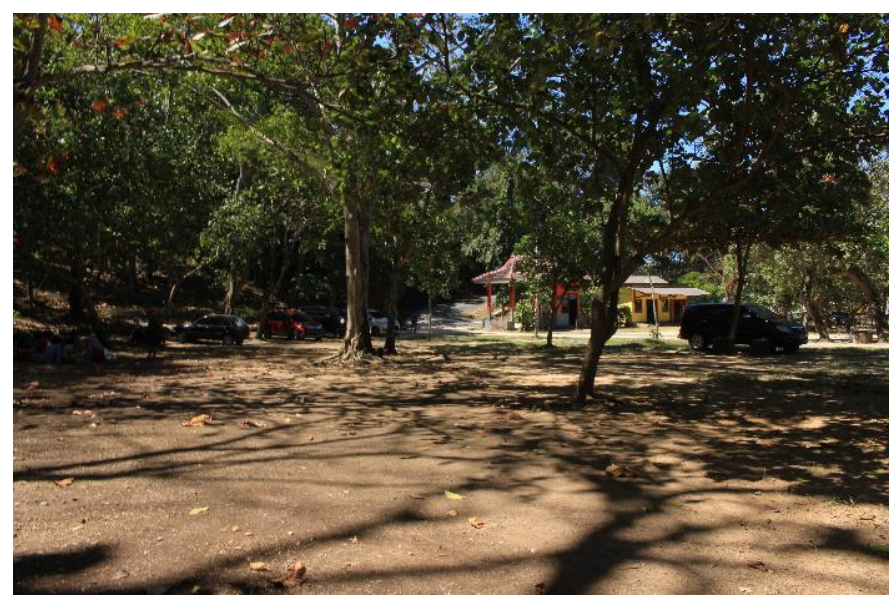

Fig. 7. An Empty Land at Western Gateway of Sendang Biru Beach (source: personal documentation of researcher, 2019).

According to researchers survey, the empty land at western of gateway of Sendang Biru Beach could be used as a center of edutourism. That center contains so many information about Sendang Biru. It started from the history of Sendang Biru, the marine potency of Sendang Biru Beach, tuna fish as the main economic potency, until the socio-culture of inhabitants in Sendang Biru. These objects could be developed more to increase the interest of local and international tourist.

Furthermore, Sendang Biru needed more attention in the beach. In addition, a portion of the coastline has been constructed of concrete to reduce abrasion, so the coastline has narrowed due to the construction of the concrete. Then the weakness in terms of development is the lack of attention from the government for the development of Sendang Biru beach itself in terms of tourism [21]. Besides the lack of awareness of the surrounding community in the management and development of the beach. On certain days, fishermen often dispose of their waste oil in Sendang Biru waters. Especially when the time of fish season where the number of fishing boats increased a lot. Because not only local fishermen who fish there, but there are also migrant fishermen from outside the city.

However, the opportunity in developing Sendang Biru Beach tourism itself is actually quite high. By slightly improving management and adding infrastructure at tourist sites, it can attract more visitors. Then there are characteristics in Sendang Biru tour, which is around the waters around Sendang Biru beach with a rented boat [22]. Surrounding communities who own boats have used them well.

\section{CONCLUSION}

The coastal tourism in southern Malang is intensively developed by the district government and surrounding communities. In various coastal villages in southern Malang already competing with one another to open coastal tourism. Almost along the rows of the south coast of Malang lined with lots of tours that shows the beauty of its beaches. Therefore, it still needs a management and also development to increase the attractiveness of the community to visit. On the other side, tourism will attract developments of the other various sectors. The development of marine edutourism on Sendang Biru Beach will make this area more attractive to tourists. This because of no one coastal area in southern Malang has developed through marine edutourism. With the support of great marine potencies, Sendang Biru Beach become the first beach area that presents marine educational content around southern Malang.

\section{REFERENCES}

[1] Evi Fitriana. "Strategi Pengembangan Taman Wisata Kum Kum sebagai Wisata Edukasi di Kota Palangkaraya", dalam Jurnal Pendidikan Geografi: Kajian, Teori, dan Praktik dalam Bidang Pendidikan dan Ilmu Geografi, Tahun 23, Nomor 2, Jun 2018, hlm: 94-106.

[2] Edi Suarto. "Pengembangan Objek Wisata Berbasis Analisis SWOT". Jurnal Spasial, Vol. 3, No. 1, Februari 2017.

[3] Jason, M. S., Lam, Bik Kai, Sia, Crystal Bee Chen, Ooi, Mei ling, Goh. "Edutourism: The Study of Tourism Behaviour of International Students in Malaysia", Proceeding of the International Conference on Social Sciences, Economic and Arts 2011, page. 207-212. In Hotel Equatorial Bangi-Putrajaya, Malaysia, 14 - 15 January 2011.

[4] Eko Aprielliyosa Efendi. "Pengembangan Media Edu-tourism Berbasis Video untuk Kawasan Desa Wisata Pesisir", in Research Report Universitas Muhammadiyah Surakarta, 2018, page. 1-16.

[5] Koroy, Kismanto et al. "Pengembangan Ekowisata Bahari Berbasis Sumberdaya Pulau-pulau Kecil di Pulau Sayafi dan Liwo, Kabupaten Halmahera Tengah". Dalam Jurnal Teknologi Perikanan dan Kelautan, Vol. 8, No. 1, Mei 2017, hlm. 1-17.

[6] Joko Sayono et al. "Utilization of Syphon Metro Kepanjen as Outdoor Learning Site for History Students", in Advances in Social Science, Education and Humanities Research, Vol. 320, 2019, page. 69-73.

[7] Interview to Yudi, 1 May 2019 (Parking man at Sendang Biru Beach).

[8] Fenny Widiana \& Respati Wikantiyoso. "Implementasi Kearifan Lokal dalam Strategi Pengembangan Wisata Pantai Sendang Biru untuk Pelestarian Pulau Sempu", dalam LOCAL WISDOM, 10 (1) 2018, page. 9-17.

[9] Georgia Yfantidou \& Dimitrios Goulimaris. "THE EXPLOITATION OF EDUTOURISM IN EDUCATIONAL SOCIETY: a Learning Experience Necessity Through Physical Activity and Recreation", in Sport Science: International Scientific Journal of Kinesiology, 2018, page. 8-15.

[10] Mordahai Siburian et al. "Strategi Pengembangan Wisata Edukasi di Godong Ijo Depok dengan Experiential Marketing", in Journal of Tourism Destination and Attraction, Vol IV, No. 2, June 2017, page.1118.

[11] Pradono Joanes De Deo. "Peranan Survei Hidrografi untuk Perencanaan Lokasi Pembangunan Pelabuhan", dalam Spectra, No. 10., Vol. 5, Juli 2007, page. 1-19. 
[18] Givari Jokowali, "Kisah Sendangbiru dan Melestarikan Tradisi Jawa", dalam https://www.terakota.id/kisah-sendangbiru-dan-melestarikantradisi-jawa/. Diakses tanggal 28 Juni 2019, pukul 13.46 WIB.

[13] Dokumen Kajian Resiko Bencana (KRB) Kabupaten Malang 2013-2017. Page. 1-40.

[14] Luthfi et al, "Pemantauan kondisi substrat menggunakan metode reef check di Perairan Selat Sempu, Kabupaten Malang", dalam Depik: Jurnal Ilmu-ilmu Perairan, Pesisir dan Perikanan, Vol. 6, No. 1, April 2017, hlm. 72-80.

[15] Kronik Sejarah Pasamuan Sendang Biru 1955.

[16] Bhimo Rizky Samudro et al. "Mengkaji Jaringan Modal Sosial Nelayan dan Dampak Keragaman Etnis di Kehidupan Nelayan Pantai Sendang Biru Kabupaten Malang", in Proceeding Seminar Nasional Peluang dan Tantangan Menghadapi Masyarakat Konomi ASEAN (MEA): Perspektif Hukum dan Perlindungan Sumber Daya Laut,page. 391-405. Universitas Muhammadiyah Yogyakarta, Saturday 25 April 2015.

[17] Khoirul Fuddin. "Nelayan Tuna Sendang Biru", in https://www.academia.edu/5225252/Nelayan_Tuna_Sendang_Biru. Accessed on 11 July 2019 at 04.36 pm.

[19] "Wow, Tuna Yellow Fin Sendang Biru Diekspor hingga Uni Eropa", dalam https://www.jawapos.com/ekonomi/26/08/2018/wow-tunayellow-fin-sendang-biru-diekspor-hingga-uni-eropa/. Accessed in 11 August 2019 on 03.00 pm.

[20] Zainul Arifin. "Getting to know the Tuna Fishing Equipment in Sendang Biru”, in https://www.wwf.or.id/en/news_facts/blog/?48082/Getting-toknow-the-Tuna-Fishing-Equipment-in-Sendang-Biru. Accessed in 11 August 2019 on 03.00 pm.

[21] Interview to Ristin, 1 May 2019 (food and beverage trader at Sendang Biru Beach).

[22] Interview to Supardi, 1 May 2019 (One of the ship owners at Sendang Biru Beach).

[23] Rahmawati HFI. Pengembangan Program Wisata Pendidikan di Wana Wisata Gunung Puntang. Skripsi. Bandung: UPI, 2013. 